\title{
Intravascular and Endobronchial DNA Delivery to Murine Lung Tissue Using a Novel, Nonviral Vector
}

\author{
JOLANTA F. KUKOWSKA-LATALLO,${ }^{1}$ EWA RACZKA, ${ }^{2}$ ANTONIO QUINTANA, ${ }^{2}$ CHUNLING CHEN, ${ }^{1}$ \\ MICHAL RYMASZEWSKI, ${ }^{3}$ and JAMES R. BAKER, JR. ${ }^{1}$
}

\begin{abstract}
Gene transfer to the lung can be achieved via either the airway or the pulmonary vasculature. We evaluated gene transfer and expression by intravascular and endobronchial routes, using DNA complexed with G9 PAMAM dendrimer or naked plasmid DNA. Intravascular tail vein delivery of dendrimer-complexed pCF1CAT plasmid resulted in high levels of transgene expression in the lung at 12 and $24 \mathrm{hr}$, followed by a second peak of expression 3 to 5 days after administration. After intravenous administration of the complexes, CAT expression was never observed in organs other than the lung. There were only minimal levels of CAT protein expressed in the lung after intravenous administration of naked plasmid DNA. Repeated intravascular doses of the dendrimer-complexed plasmid, administered four times at 4-day intervals, maintained expression at 15-25\% of peak concentrations achieved after the initial dose. Endobronchial delivery of naked pCF1CAT plasmid produced significant amounts of CAT protein in the lung. Comparison of intratracheal and intranasal routes resulted in similar expression levels of CAT in the lung and trachea. However, in juxtaposition to vascular delivery, intranasal delivery of dendrimer-complexed plasmid DNA gave lower levels of CAT expression than that observed with naked plasmid DNA. In situ localization of CAT enzymatic activity suggested that vascular administration seemed to achieve expression in the lung parenchyma, mainly within the alveoli, while endobronchial administration primarily targeted bronchial epithelium. Our results show that intravenously administered G9 dendrimer is an effective vector for pulmonary gene transfer and that transgene expression can be prolonged by repeated administration of dendrimer-complexed DNA.
\end{abstract}

\section{OVERVIEW SUMMARY}

Expression vector-m ediated gene therapy has been used to deliver the cystic fibrosis transmembrane conductance regulator (CFTR) and $\alpha_{1}$-antitrypsin $\left(\alpha_{1}\right.$-AT) genes to the lung. Different carriers to deliver DNA, such as viruses or liposomes, have been found to be inefficient or inflammatory in human subjects in vivo, highlighting the need to search for better gene transfer system $s$. The present study investigates the ability of PAMAM dendritic polymers (dendrimers) to augment plasmid DNA gene transfer in vivo and evaluates the targeting of the lung by alternative routes of administration. Dendrimer-complexed plasmid DNA delivered via the vasculature system increased transgene expression 20-40 times over DNA administered alone and appeared to target mainly the alveoli in the peripheral lung (possibly type II pneumocytes). Naked plasmid DNA was efficiently expressed when delivered either intranasally or intratracheally, and the expressed protein was localized primarily in the ciliated epithelium of the lung and trachea. Repeated intravascular administration of dendrimer-complexed DNA resulted in gene expression for up to 16 days with CAT protein concentration reaching $15-25 \%$ of the peak values observed after a single administration.

\section{INTRODUCTION}

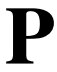
ULMONARY DISEASES are potentially treatable by gene transfer for a number of reasons. The genetic bases for common

\footnotetext{
${ }^{1}$ Department of Internal Medicine, University of Michigan Medical School, Ann Arbor, MI 48109.

${ }^{2}$ Department of Pharmacology, Faculty of Medicine and Odontology, University of the Basque Country, 48940 Leioa, Spain.

${ }^{3}$ Molecular Research Center, Cincinnati, OH 45212.
} 
inherited pulmonary diseases such as cystic fibrosis (CF) and $\alpha_{1}$-antitrypsin deficiency $\left(\alpha_{1}\right.$-AT) (Crystal et al., 1989; Kerem et al., 1989; Collins, 1992) and for lung cancer (Taya et al., 1984; Lee et al., 1995) are being elucidated. There are no effective therapies for these or other pulmonary disorders such as malignant mesothelioma, a unique localized intrathoracic malignancy without a major metastatic component (Lee et al., 1986). Chronic inflammatory lung diseases such as idiopathic pulmonary fibrosis (IPF) and asthma are localized to the lung, but lack adequate treatments (Carrington et al., 1978; TurnerWarwick et al., 1980; Demoly et al., 1997). Advances in understanding the physiologic basis of these diseases indicate that therapeutic benefits may result from the expression of cytokines, surfactants, antioxidant enzymes, or mucoproteins (McElvaney et al., 1991; Christman et al., 1993; Conary et al., 1994; Piguet and Vesin, 1994; Wang et al., 1994; Rogy et al., 1995).

The lung is accessible either directly through the airway or through the vascular system. This offers the possibility to achieve gene transfection to the endothelial cells, as well as to the lung parenchyma (Zhu et al., 1993). However, the utility of endobronchial delivery may be limited by the need for special formulations or by mucociliary clearance of the therapeutic (Clarke and Pavia, 1991). Despite this, the respiratory epithelium has been a primary target for CF transmembrane conductance regulator (CFTR) gene therapy for a number of years (Trapnell et al., 1991; Rosenfeld et al., 1992; Hyde et al., 1993; Wagner et al., 1995). In animal models, gene transfer was achieved with a variety of endobronchially administered gene transfer vectors including viruses, lipids, or naked plasmid DNA. The advantages and safety issues associated with these approaches have been well characterized and described (Brigham et al., 1989; Hazinski et al., 1991; Rosenfeld et al., 1991; Stribling et al., 1992; Alton et al., 1993; Mastrangeli et al., 1993; Canonico et al., 1994; Yei et al., 1994; Zabner et al., 1994; Tsan et al., 1995). Several attem pts to modify viral vectors to prevent immune response that causes systemic toxicity (Mack et al., 1997), and to improve the formulations of cationic liposomes for in vivo transfection (Schughart et al., 1999), have not been entirely successful. Thus, the further progress of human gene therapy depends on the developm ent of safe and more efficient vector systems.

We have previously studied the characteristics and the efficiency of polyamidoamine (PAMAM) dendritic polymers (dendrimers) as vectors for gene transfer both in vitro (Bielinska et al., 1996, 1997; Kukowska-Latallo et al., 1996, 1999) and in vivo in murine cardiac transplants (Qin et al., 1998). Furthermore, we have reported that naked plasmid DNA can transfect mouse airway epithelium in vivo, and we have established that surfactant can be a major factor inhibiting this process (Raczka et al., 1998). The present work compares transgene expression from chloramphenicol acetyltransferase (CAT) expression plasmid achieved in vivo in the mouse lung after either intravenous or endobronchial administration. The expression of naked plasmid is compared with that observed when plasmid DNA is complexed with dendritic polymer as a nonviral vector. The results demonstrate that each delivery route requires different vectors to achieve optimal transgene expression, that each approach appears to target different cells within the lung, and that an ex- tended expression of a transgene can be achieved with intravascular delivery of dendrimer-complexed DNA.

\section{MATERIALS AND METHODS}

\section{Plasmid DNA}

The pCF1CAT plasmid used in this study was provided by R. Scheule and S. Cheng (Genzyme, Framingham, MA). The construction and optimization of this plasmid have been previously described (Lee et al., 1996; Yew et al., 1997). As a control for both in situ detection and biochemical evaluation of transfection, the previously described plasmid pCF1Luc expressing the luciferase gene was used (Raczka et al., 1998). Plasmid DNA was purified through the double cesium chloride gradient and then dialyzed. Preparations were assayed for endotoxin level, protein contamination, and Escherichia coli DNA content in the Human Applications Laboratory and Vector Core Laboratory at the University of Michigan (Ann Arbor, MI). In preliminary studies, endotoxin contamination of plasmid preparations was correlated with decreased chloramphenico 1 acetyltransferase (CAT) expression and toxicity when the DNA was complexed with dendrimer and administered intravascularly. Consequently, we have used plasmid preparations with endotoxin concentrations less than $1 \mathrm{EU} / \mathrm{mg}$ of DNA for the experiments presented in this report (Table 1).

\section{Polymer vector}

Polyamidoamine (PAMAM) dendrimers, well-defined synthetic polymers, have been previously described (KukowskaLatallo et al., 1996). Dendrimers form complexes with DNA through electrostatic interactions between negatively charged phosphate groups in the nucleic acid and positively charged amino groups on the polymer. In the current study, we have used a ninth generation of dendrimer (G9) with an ethylenediamine initiator core (EDA). This polymer is a spherical molecule with a diameter of approximately $114 \AA$, a molar mass of $467 \mathrm{kDa}$, and 2048 surface primary amino groups per molecule. The choice of the polymer was based on our prior in vitro and in vivo transfection studies (Kukowska-Latallo et al., 1996, 1999; Bielinska et al., 1997; Qin et al., 1998) and preliminary toxicity studies.

\section{Polymer-DNA complex formation}

In the current work, plasmid DNA not complexed with dendrimer and delivered in saline solution or in water is referred to as naked plasmid DNA. Complexes of dendrimer and plasmid DNA were formed by mixing in physiological saline $(0.9 \%$ $\mathrm{NaCl}$ in sterile water) for intravascular delivery or in water for intranasal delivery. The G9 EDA dendrimer has been used at a charge ratio of polymer to DNA of 5 for intravenous administration and of 1,5 , or 10 for endobronchial administration.

\section{Animals}

Female BALB/c mice, 35-45 days old and weighing 18-20 g (Charles River Laboratories, Wilmington, MA) were used in all experiments. The experiments were approved and complied 
Table 1. Quality of Plasmid DNA Preparation and the Efficacy of Transfection Measured by CAT Expression ${ }^{a}$ in the Lung after Intravenous Delivery of pCF1CAT DNA/G9 EDA Dendrimer Complex ${ }^{\mathrm{b}}$

\begin{tabular}{lcccc}
$\begin{array}{l}\text { pCF1 CAT DNA } \\
\text { preparation no. }\end{array}$ & $\begin{array}{c}\text { E. coli DNA } \\
(\%)\end{array}$ & $\begin{array}{c}\text { Protein } \\
(\text { ng/ } \mu \mathrm{g})\end{array}$ & $\begin{array}{c}\text { Endotoxin } \\
(\text { EU/mg) }\end{array}$ & $\begin{array}{c}\text { CAT } \\
\text { at days } \\
\text { (ng/g protein) }\end{array}$ \\
\hline 3 & 2.3 & 0.53 & 13 & $6.2($ lethal) \\
6 & 2.7 & 0.59 & 3.3 & $23.7 \pm 9.0$ \\
8 & 1.7 & $<0.15$ & $<0.23$ & $34.1 \pm 9.7$ \\
\hline
\end{tabular}

${ }^{a}$ Nanograms per gram of soluble protein.

${ }^{b}$ Preparation 3 was lethal for two of three mice tested.

with the guidelines of the University of Michigan Committee on the Use and Care of Animals.

\section{Intravascular and endobronchial delivery studies}

The time course of CAT expression in the lung was examined after intravenous administration of dendrimer $(650 \mu \mathrm{g})$ complexed plasmid DNA (200 $\mu \mathrm{g}$ ) or naked plasmid DNA (200 $\mu \mathrm{g})$ at 6 and $12 \mathrm{hr}$, and $1,2,3,4,5$, and 7 days after delivery. The control groups of animals received either pCF1LucDNA $(200 \mu \mathrm{g})$, naked or complexed with dendrimer, or physiological saline $(200 \mu \mathrm{l})$, and were killed after $12 \mathrm{hr}$ or 4 days postdelivery. In experiments in which one to four repeated doses were administered, the animals were killed 4 days after the last dose. Additional groups of mice were killed $12 \mathrm{hr}$ after the first and fourth administration. Transfection was also evaluated in the heart, kidneys, pancreas, liver, spleen, and lymph nodes 12 $\mathrm{hr}$ and 4 days after the intravenous administration of dendrimercomplexed DNA. Intravascular delivery was accomplished by immobilizing mice in a small Plexiglas box and injecting samples via the tail vein. The DNA-dendrimer or DNA solutions were delivered in a $200-\mu 1$ volume of physiological saline, using a 27-gauge needle attached to a 1-ml syringe. Groups of mice receiving repeated intravascular administrations were injected 4 days apart on one to four occasions for each group, with lung tissue harvest performed 4 days after the last delivery. Tissue was also obtained from a group of animals $12 \mathrm{hr}$ after the first and fourth administration.

For endobronchial delivery, naked plasmid DNA $(100 \mu \mathrm{g})$ or complexed with dendrimer $(65-650 \mu \mathrm{g})$ was prepared in 100 $\mu 1$ of sterile water. The different dendrimer-DNA charge ratios, as well as possible differences between intranasal and intratracheal administration and possible differences in transfection between the trachea and the lung tissues, were evaluated. Mice administered with either pCF1Luc (100 $\mu \mathrm{g})$ or physiological saline $(100 \mu 1)$ were included in each type of experiment. Intranasal delivery was performed on mice anesthetized with methoxyflurane (Metofane; Mallinckrodt Veterinary, Mundelein, IL) inhalation. They were held supine with the head slightly elevated and the mouth closed. A $100-\mu 1$ volume of transfection mixture was delivered quickly from a $200-\mu 1 \mathrm{mi}-$ cropipette tip, directly through the nasal orifices during respiration. Intratracheal instillation was performed by a modification of the method of Otto-Verberne et al. (1992). Mice under methoxyflurane anesthesia were held in an upright position by suspending them on their front teeth. The light tip of a fiberop- tic light was placed against the skin of the animal at throat level. After the tongue was extended from the mouth, the trachea, visible as a white ring, was quickly intubated with a 20 -gauge venous catheter attached to a 1-ml syringe. Transfection solution $(100 \mu 1)$ was injected through the glottis into the trachea and the catheter was removed. The animals then remained in a vertical position for a few seconds after the instillation.

\section{Harvesting and processing of tissue}

At different time points from $6 \mathrm{hr}$ to 16 days after the first plasmid delivery, during deep anesthesia with Metofane, the abdominal cavity of each mouse was opened and the mice were bled out through cutting the abdominal aorta and the vena cava. The chest was then opened and the pulmonary vascular bed was flushed by slowly injecting $3 \mathrm{ml}$ of phosphate-buffere $\mathrm{d}$ saline (PBS) into the right ventricle of the heart. The trachea and the lungs were excised and removed en bloc, then weighed and washed in PBS. An appropriate cold lysis buffer was added at $1 \mu 1 / \mathrm{mg}$ of tissue (lysis buffer for CAT enzyme-linked immunosorbent assay [ELISA] proprietary to Boehringer Mannheim [Indianapolis, IN] was supplemented with aprotinin [5 $\mu \mathrm{g} / \mathrm{ml}$ ], $5 \mathrm{~m} M$ 1,4-dithiothreitho 1 [DTT, Cleland's reagent], and $0.2 \mathrm{~m} M$ phenylmethylsul fonyl fluoride [PMSF]). The tissue was homogenized with a tissue homogenizer (Biospec Products, Bartlesville, OK) for $30 \mathrm{sec}$, and then frozen in liquid nitrogen and stored at $-80^{\circ} \mathrm{C}$ until assayed. For assessment of distribution of expression to organs other than the lung, tissue was harvested from the heart, kidneys, pancreas, liver, spleen, and lymph nodes.

\section{CAT ELISA}

To quantify CAT expression tissue homogenate lysate was centrifuged at $12,000 \times g$ for $10-15 \mathrm{~min}$ at $4^{\circ} \mathrm{C}$. The amount of CAT protein was measured in $50 \mu 1$ of the supernatant by an ELISA (Boehringer Mannheim). It was adjusted for the concentration of the total soluble protein present in the sample as measured by the bicinchoninic acid (BCA) protein assay (Pierce, Rockford, IL) with bovine serum albumin as the standard.

\section{Histochemical staining of CAT activity}

To obtain cryostat sections, lung tissue was prepared by washing the pulmonary vascular bed with PBS. This step was followed by closure with a suture of the left main bronchus. The right lung was infused through the trachea with embedding 
medium for frozen tissue specimens (O.C.T. medium; Sakura Finetek USA, Torrance, CA) and frozen in O.C.T. medium in liquid nitrogen. The left half of the lung was used to obtain homogenate for measurement by CAT ELISA. Histochemical staining CAT activity was performed on tissue slides with freshly frozen sections, using the CAT staining kit from Boehringer Mannheim. The Hatchett's Brown precipitate is produced by acetyltransferase activity, which generates the free sulfhydryl group of CoA, resulting in the reduction of ferricyanide to ferrocyanide. The ferrocyanide then complexes with copper ions to form the precipitate.

\section{Statistical analysis}

Statview 4.5 (Abacus Concepts, Berkeley, CA) was used for the statistical analysis. At least five mice were used for each data point. All assays were performed in triplicate on individual lung homogenates and presented as averages. Data were compared by one-way analysis of variance (ANOVA). All values were expressed as means \pm SEM, and $p$ values less than 0.05 were considered significant.

\section{RESULTS}

\section{CAT expression after intravascular delivery}

The highest levels of intrapulmonic transgene expression were observed when pCF1CAT DNA $(200 \mu \mathrm{g})$ complexed with dendrimer (650 $\mu \mathrm{g}$ of G9 EDA) was administered intravascularly in physiological saline $(200 \mu \mathrm{l})$ (Fig. 1). Significant amounts of CAT protein $(14.8 \pm 3.1 \mathrm{ng} / \mathrm{g}$ soluble protein $)$ were already found in lung tissue at $6 \mathrm{hr}$, with the highest level at $12 \mathrm{hr}$ after administration $(93.4 \pm 10.4 \mathrm{ng} / \mathrm{g})$. CAT concentrations then declined 1 day $(66.1 \pm 9.7 \mathrm{ng} / \mathrm{g})$ and 2 days $(13.5 \pm$
$2.4 \mathrm{ng} / \mathrm{g}$ ) after injection of the complex. A second wave of CAT expression began on day $3(22.6 \pm 5.4 \mathrm{ng} / \mathrm{g})$, peaked on day 4 $(34.1 \pm 3.7 \mathrm{ng} / \mathrm{g})$, and decreased thereafter on days 5 and 7 postadministration $(15.7 \pm 1.7$ and $3.8 \pm 0.6 \mathrm{ng} / \mathrm{g}$, respectively; Fig. 1). Intravascular delivery of naked plasmid DNA yielded low levels of CAT protein $(0.6-3.5 \mathrm{ng} / \mathrm{g}) 12 \mathrm{hr}$ to 7 days after administration (Fig. 1). No CAT protein was detected in the lungs of control mice treated with either naked pCF1Luc DNA or physiological saline (data not shown).

There appeared to be no cumulative effect from repeated doses of dendrim er-complexed DNA (up to four doses at 4-day intervals), as the level of CAT protein in the lung never exceeded that observed with a single administration. As shown in Fig. 2, the amount of expressed CAT protein, measured $12 \mathrm{hr}$ and 4 days after the fourth dose, was at $15-25 \%$ of the levels achieved after the initial dose. Naked plasmid DNA, administered repeatedly at 4-day intervals, was expressed at low levels (under $4 \%$ of the maximal expression achieved with dendrimercomplexed DNA) throughout the 16-day period of the study (data not shown). Expression after intravascular delivery of a single dose of dendrimer-com plexed DNA (650 $\mu \mathrm{g}$ of G9 EDA with $200 \mu \mathrm{g}$ of pCF1CAT) monitored at $12 \mathrm{hr}$ and 4 days was localized exclusively in the lung and not in the spleen, heart, liver, pancreas, kidneys, and lymph nodes (data not shown). Mice injected with naked plasmid DNA had no significant CAT activity in any of the organs tested (data not shown).

\section{Expression of CAT after endobronchial delivery}

In contrast to intravascular delivery, endobronchial administration of naked pCF1CAT plasmid produced significant amounts of CAT protein (15-20 ng/g soluble protein) after intranasal delivery of 50 or $100 \mu \mathrm{g}$ of DNA in $100 \mu \mathrm{l}$ of sterile water (Table 2). Maximum CAT expression $(17.5 \pm 2.7 \mathrm{ng} / \mathrm{g}$ protein) was observed after intranasal delivery of $50 \mu \mathrm{g}$ of plas-

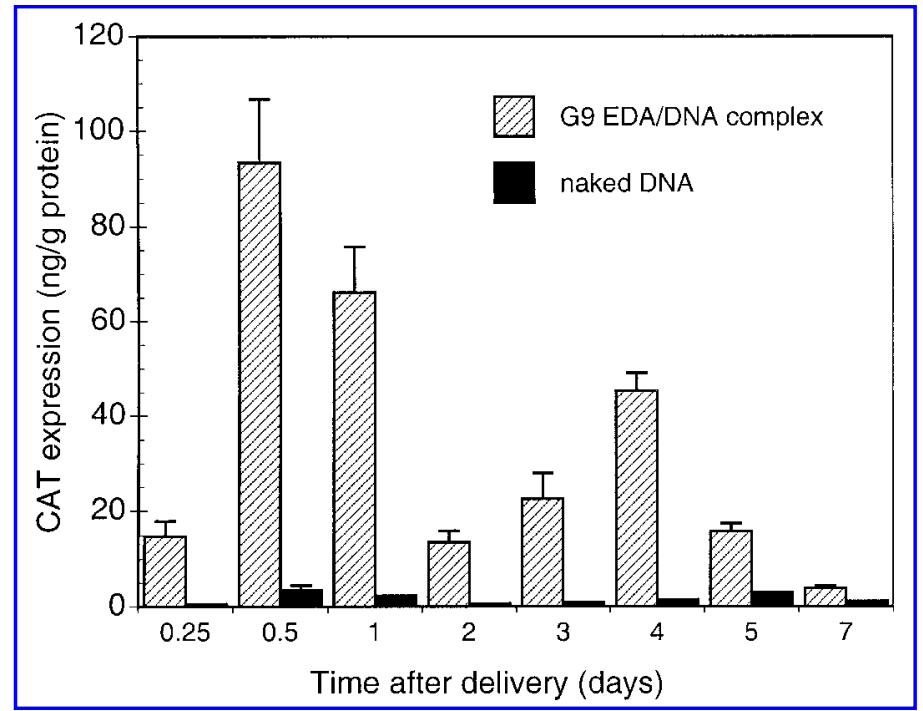

FIG. 1. Time course of CAT gene expression in the mouse lung after intravascular delivery. G9 EDA dendrim er (650 $\mu \mathrm{g})$ complexed with plasmid pCF1CAT DNA $(200 \mu \mathrm{g})$ was delivered intravenously in $200 \mu 1$ of saline (charge ratio of 5). Compared with the expression level of naked DNA, CAT expression was increased at 6 and $12 \mathrm{hr}$, and at days 1, 2, 3, 4, and 5 after delivery, with the highest level at $12 \mathrm{hr}$ and a second peak at day 4 , and the lowest level at day 7 . The values are the means \pm SEM of $6,7,7,5,6,7,7$, and 7 mice for G9 EDA-DNA complexes, respectively. The values for mice that received naked plasmid DNA are averages from two mice, except for the value at $12 \mathrm{hr}$, where four mice were used. 


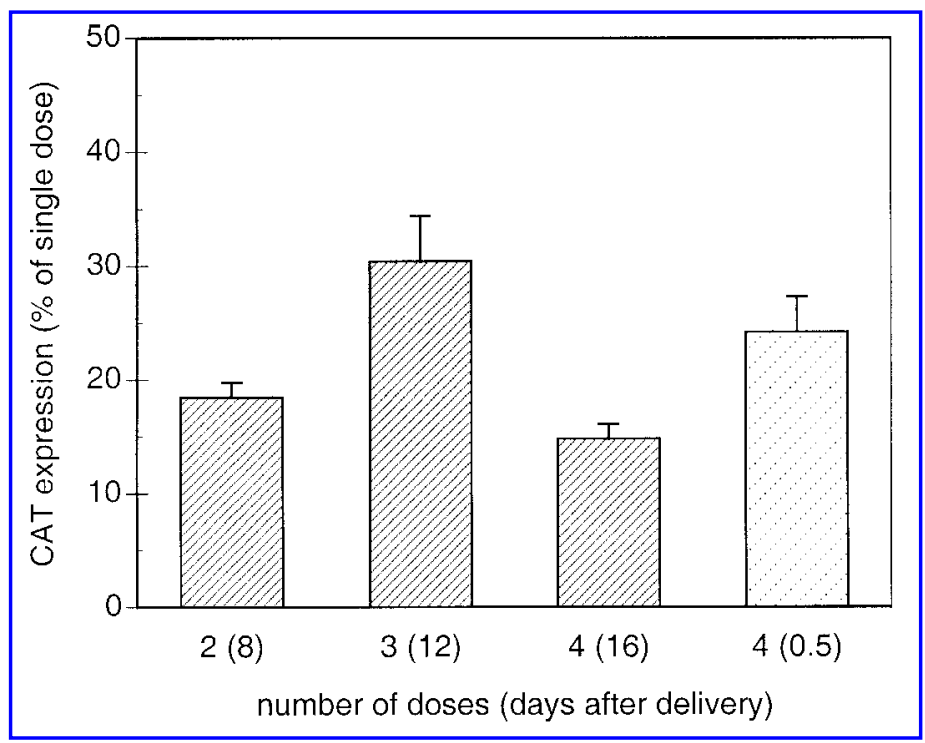

FIG. 2. Expression of CAT gene in the lung after multiple intravascular doses of G9 EDA dendrimer $(650 \mu \mathrm{g})$ complexed with pCF1CAT DNA $(200 \mu \mathrm{g})$ in $200 \mu \mathrm{l}$ of saline. Complexes were delivered repeatedly (one, two, three, and four times) every 4 days and harvested 4 days after the last delivery and $12 \mathrm{hr}$ after the fourth dose. The level of expressed CAT protein was significantly lower $(p<0.001)$ after two doses $(8$ days) compared with the maximal level of a single dose, and remained at a similar level for four doses (16 days). The values for multiple doses (two, three, and four) are the means \pm SEM of six or seven mice.

mid and did not increase when larger amounts of DNA (100 $\mu \mathrm{g}$ ) were used (Table 2). Delivery of dendrimer G9 EDA-complexed plasmid DNA through the same route gave lower values of CAT expression than did naked DNA (Table 2). Moreover, increases of up to 10 -fold in the amount of dendrimer in the complex (increasing the charge ratio of dendrimer to DNA from 1 to 10) further reduced the level of CAT expression (Table 2). Delivery of naked plasmid DNA, either intranasally or through an intratracheal catheter, did not yield significantly different levels of CAT expression in either lung or trachea tissues (Fig. 3).

Comparison of intranasal delivery of naked plasmid DNA (100 $\mu \mathrm{g}$ of pCF1CAT DNA) with intravascular delivery of dendrimer-complexed DNA (650 $\mu \mathrm{g}$ of G9 EDA with $200 \mu \mathrm{g}$ of pCF1CAT DNA) demonstrated that threefold higher CAT expression could be achieved from the intravenous route $(p<$ 0.01) (Fig. 4).

Table 2. Effect of Complexing G9 EDA Dendrimer with pCF1CAT Plasmid DNA at Charge Ratios From 1 to 10 on Gene Expression a in the Lung after Intranasal Delivery of Complexes Compared with Naked Plasmid DNA ${ }^{b}$

\begin{tabular}{lrr}
\hline & \multicolumn{2}{c}{ Plasmid DNA } \\
\cline { 2 - 3 } G9 EDA/DNA ratio & \multicolumn{1}{c}{$50 \mu \mathrm{g}$} & $100 \mu \mathrm{g}$ \\
\hline (Naked DNA) & $17.5 \pm 2.7$ & $16.5 \pm 2.0$ \\
1 & $8.6 \pm 1.9$ & $12.3 \pm 1.6$ \\
5 & $0.9 \pm 0.2$ & $1.7 \pm 0.4$ \\
10 & $0.5 \pm 0.1$ & $0.8 \pm 0.2$ \\
\hline
\end{tabular}

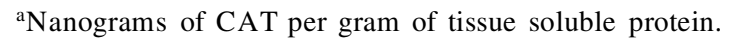

${ }^{\mathrm{b}}$ All values are the means \pm SEM of eight mice. Expression was significantly higher (at least $p<0.01$ ) for naked DNA compared with the complexes.

\section{Histopathology and localization of expressed CAT protein}

Histopathology did not reveal any changes, hemorrhage, or treatment-related damage to the lung. In particular, inflammation, neutrophils, or frank pneumonitis was not observed. Hematoxylin- and eosin (H\&E)-stained histologic sections showed the presence of dendrimer-DNA complexes in lung parenchyma. Large DNA-dendrimer complexes observed on H\&E slides by visual microscopy were found not to be associated with CAT expression, detected by CAT staining of a slide containing the consecutive tissue section.

CAT protein was detected in situ in the right lung by the histochemical staining technique described in Materials and Methods. Preliminary studies showed evidence of CAT protein enzymatic activity 4 days after intravenous delivery of polymer-complexed DNA (650 $\mu \mathrm{g}$ of G9 EDA with $200 \mu \mathrm{g}$ of pCF1CAT). In situ localization of the CAT protein in lung revealed uniform distribution in the alveolar epithelium (Fig. 5A and B). Control animals received either dendrimer-com plexed pCF1Luc DNA (200 $\mu \mathrm{g})$ at the same charge ratio (Fig. 5D) or saline (Fig. 5E). Intranasal delivery of $100 \mu \mathrm{g}$ of naked pCF1CAT DNA resulted in localized expression primarily in the ciliated epithelium of the respiratory bronchioles and occasionally in the alveolar epithelium (Fig. 5C). The expression of CAT protein in the contralateral lung of each mouse, evaluated by ELISA, reflected the degree of staining observed with the in situ analysis (Fig. 5F).

\section{DISCUSSION}

The process of gene transfer and the achievement of functional levels of transgene expression remain a major obstacle to human gene therapy. Most of the currently employed trans- 


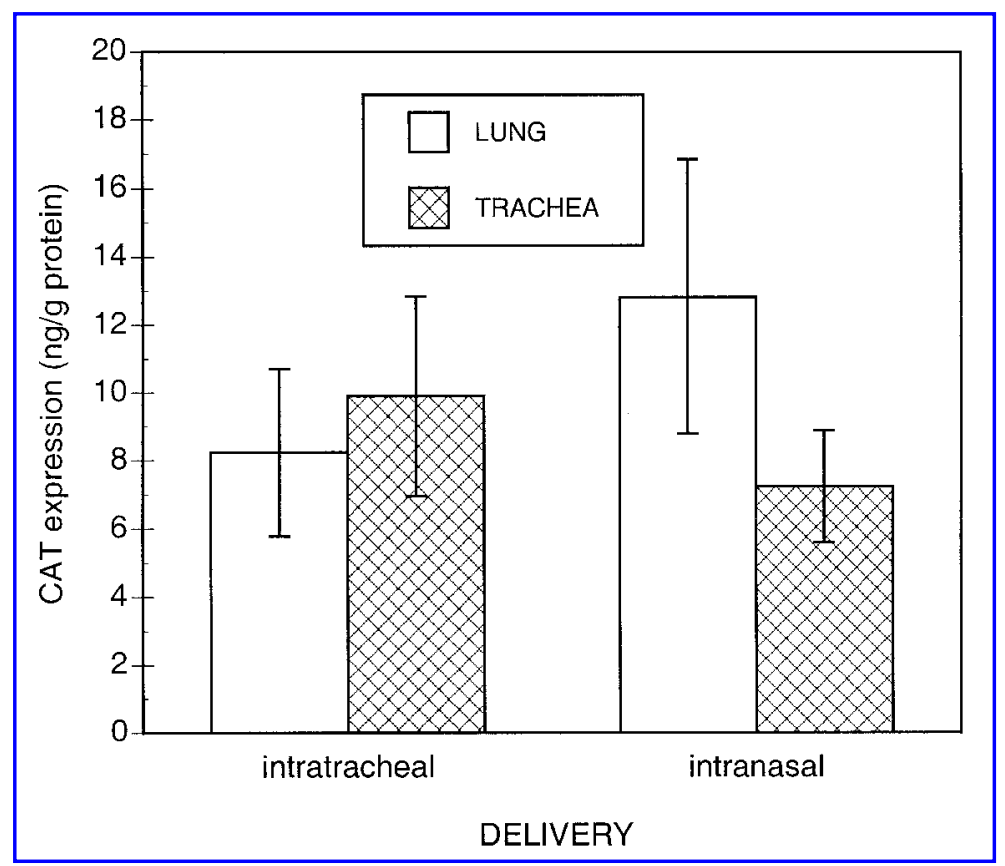

FIG. 3. Expression of CAT after intratracheal and intranasal delivery of naked pCF1CAT plasmid DNA (100 $\mu \mathrm{g})$ in lung and trachea homogenates 5 days after intratracheal or intranasal delivery. The values are the means \pm SEM from eight mice.

fection systems are inappropriate to use in the human lung (Yang et al., 1994; Worgall et al., 1997; Zabner et al., 1997; Xiao et al., 1999). Modifications may improve viral vectors; however, prudence suggests examining nonviral alternatives, from naked plasmid DNA to complex synthetic assemblies. A1though these systems have uniformly lower levels of in vivo expression when compared with the most efficient viral vectors, it has been suggested that certain therapeutic applications of pulmonary gene therapy might require only low levels of expression obtained with naked DNA. For example, in cystic fibrosis there is evidence, both in vitro (Rich et al.,1990; Johnson et al., 1992, 1995) and in vivo (Hyde et al., 1993; Zabner et al., 1993), that low levels of CFTR expression could reestablish physiological ion transport. Thus, some form of enhanced transfer of plasmid DNA may be a viable therapeutic approach for pulmonary disorders, such as antiinflamm atory gene therapy of asthma or pulmonary fibrosis (Piguet and Vesin, 1994; Demoly et al., 1997).

We were interested in evaluating gene expression in the lung from an efficient expression plasmid delivered either as naked DNA or complexed with cationic dendritic polymer, using endobronchial or intravascular delivery route. The in vivo results presented in this study demonstrate that the most effective synthetic vector to deliver DNA to the lung varies according to the

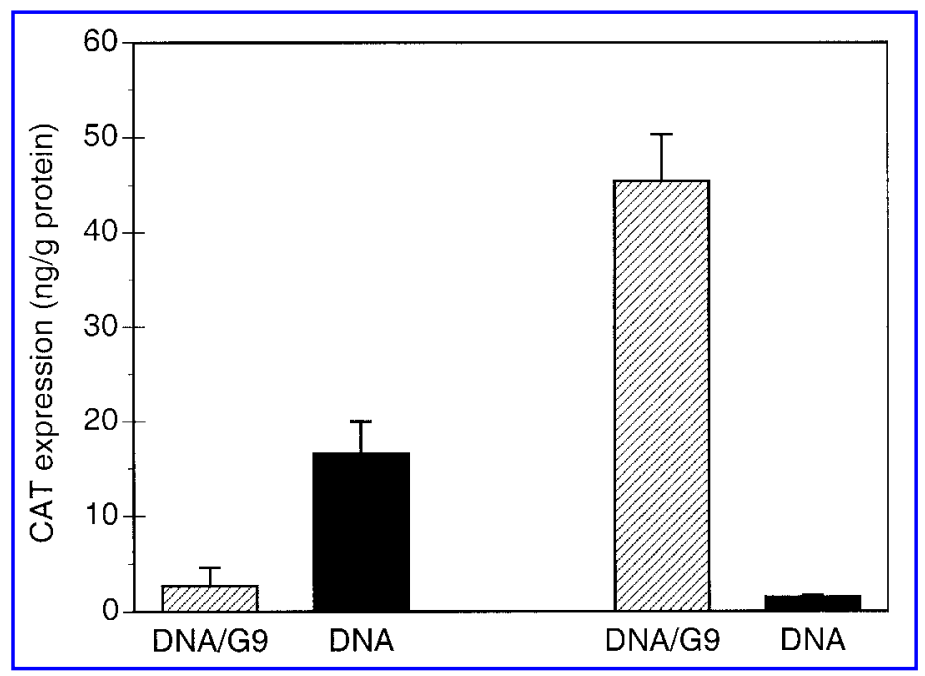

FIG. 4. Comparison of levels of CAT expression 4 days after endobronchial (left) or intravenous (right) delivery of G9 EDA complexed with pCF1CAT DNA (charge ratio of 5) or of naked plasmid DNA. Four sets represent the means \pm SEM of 3,11 , 14 , and 4 mice. 


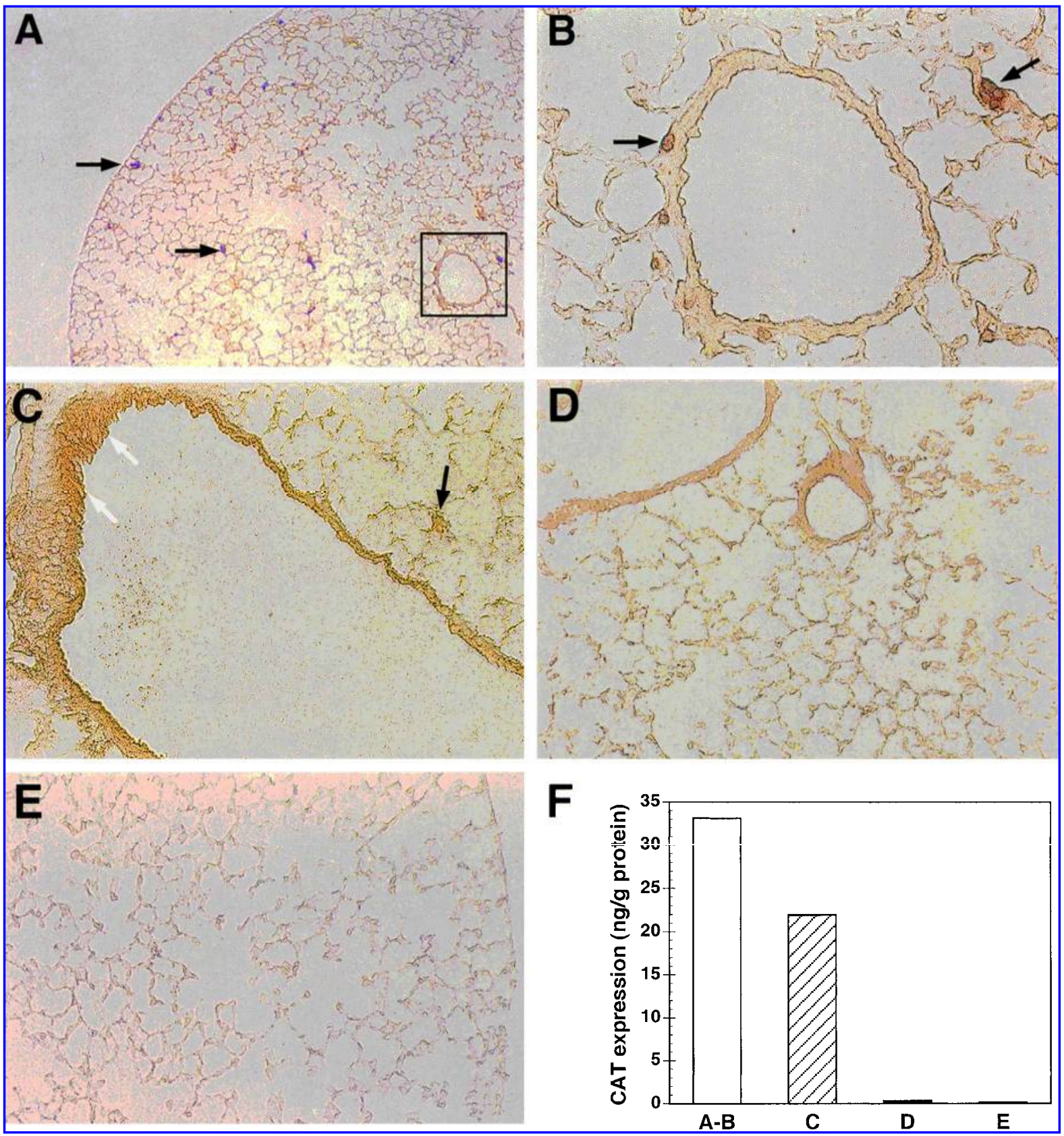

FIG. 5. Detection of CAT activity in mouse lung sections in situ 4 days after intravascular or intranasal delivery of pCF1CAT DNA. Localization of CAT protein after intravenous delivery of G9 EDA dendrimer $(650 \mu \mathrm{g})$ complexed with $200 \mu \mathrm{g}$ of pCF1CAT DNA in saline (charge ratio of 5) shows uniform distribution of Hatchett's Brown precipitate in the alveoli (A and B, black arrows). The pulmonary artery marked with the square (A) is shown enlarged (B). CAT activity is present in ciliated epithelium in columnar cells of respiratory bronchiole of peripheral lung (C, white arrows) and in pneumocyte of alveoli (C, black arrow) after intranasal delivery of $100 \mu \mathrm{g}$ of pCF1CAT DNA in water. Control mice received intravenously either $100 \mu \mathrm{g}$ of pCF1LucDNA complexed with G9 EDA $(650 \mu \mathrm{g})$ in saline $(\mathbf{D})$ or saline alone $(\mathbf{E})$. In $(\mathbf{F})$ the columns represent the level of CAT protein in the left half of the lung corresponding to the right half used for in situ panels (A-E). Original magnification: (A) $\times 100 ;(\mathbf{C}-\mathbf{E}) \times 200 ;(\mathbf{B}) \times 400$.

route of administration. Naked plasmid DNA achieved efficient expression when delivered to the respiratory epithelium by either intratracheal or intranasal administration, confirming our previous results (Raczka et al., 1998). In contrast, naked DNA administered intravenously achieved minimal expression in the lung. Intravascular administration achieved significant expression in the lung only when the plasmid was complexed with dendritic polymer. Interestingly, intravenous delivery of the dendrimer-DNA complexes achieved higher CAT protein expression in the lung than did endobronchial delivery of naked 
plasmid DNA. Neither technique resulted in expression outside the lung, nor appeared to cause acute toxicity. However, several unique features were observed with the intravenous administration of the dendrimer-DNA complex. Transgene expression after intravascular delivery of the complex has two distinct phases. An initial peak is observed at $12 \mathrm{hr}$, with a second peak at 4 days. The duration of expression after a single intravenous administration was similar to what was observed previously for intrabronchial administration of naked DNA (Raczka et al., 1998), but this expression could be maintained for longer periods of time by repeated administration. In contrast, neither naked DNA delivered intravenously nor dendrimer-DNA complex administered intrabronchially could achieve significant levels of transgene expression. This suggests that expression efficiency of different vector systems is modified by the route of administration.

The transient decrease in expression observed on days 1 and 2 after intravenous administration of the polymer-DNA complex is interesting to evaluate. As reported previously for clearance mechanisms of adenoviral vectors after intravenous administration (Worgall et al., 1997) and for retroviral gene transfer to airway epithelia (McCray et al., 1997), there is likely an innate immune system of the lung that eliminates a vector or vector-expressing cells. It is also possible that the observed slow decline at the end of the 7-day time course is the result of the development of a specific immune response to either the polymer, the DNA, or CAT protein. However, several points argue against this hypothesis. First, we have detected no antibody response to the CAT protein or the dendrimer of the dendrimer-DNA complex in these animals 16 and 72 days after repeated administration (our unpublished data). While we found no humoral response even to CAT protein, it is possible that a cellular response to this or the complex caused the decreased expression at 7 days. The absence of inflammation or injury in the lung makes this less likely. In addition, the repeated administration of the dendrimer-DNA complex maintained expression at $20-30 \%$ of peak levels, which would not occur in the presence of neutralizing immunity (Rivera et al., 1999). Finally, an immune response does not explain the second peak of expression observed 4 days postadministration. This pattern of expression could result from delayed transfection of different types of cells or a secondary release of DNA from dendrimer-DNA complexes. Both of these possibilities deserve further evaluation, as short-term transgene expression with different organ localization has been reported after liposomemediated intravascular delivery of plasmid DNA (Zhu et al., 1993). Also, further identification of time-dependent differential localization of CAT protein may help in interpreting this unusual time course of expression.

In our study the CAT transgene was exclusively localized in the lung as compared with other tissues. We have documented that the intravenous delivery employed resulted in expression prolonged for 16 days, and in a localization pattern different from that observed with endobronchially administered naked plasmid DNA. In particular, this approach yielded uniform expression of CAT protein in the alveolar pneum ocytes in the periphery of the lung. The particular cell transfected in this area is difficult to assess since there are no ultrastructural characteristics that could differentiate between type I and type II alveolar pneumocytes. However, transfection with naked DNA or vectors other than lentivirus requires mitotic activity (Naldini et al., 1996; Robbins and Ghivizzani, 1998; Mortimer et al., 1999). The alveolar type II pneumocyte is a dividing and differentiating cell that serves as a progenitor for alveolar type I pneumocyte (Bowden, 1981). Moreover, considering the location of expression, close to the alveolar septum where type I pneumocytes constitute only $7 \%$ of the alveolar septum, the type II pneumocyte seems a better candidate than the type I pneumocyte (Fig. 5).

Why administration of these complexes to the tail vein of the mice would result in this pattern of localized lung expression is not clear, especially since expression was not observed in any other organs (data not shown). It is possible that the complexed DNA (with a net positive charge) was entrapped in the circulatory system of the lung, which represents the first microvascular bed encountered after the tail vein administration. Complexing DNA with an excess of positively charged dendrimer condenses the DNA and forms complexes ranging from $10 \mathrm{~nm}$ to $1 \mu \mathrm{m}$ in diameter (Kukowska-Latallo et al., 1996). It is possible that the size of these complexes will lead to passive deposition in the vascular bed. DNA in this complex is protected from nuclease activity while transcriptionally active in vitro (Bielinska et al., 1997). Thus, this approach may aid intravascular transfection by protecting the DNA from nuclease activity before it deposits in the lung. It is also apparent that the complexes had to transverse the vascular endothelium to transfect the alveolar epithelium. The mechanism of this process is of interest as it may provide insights into intravascular gene delivery in other organs. Ours is the first report describing prolonged (up to 16 days) transgene expression after repeated administrations in this pattern in the lung, which may within this time period have therapeutic relevance in, for example, antiinflammatory therapy (Dow et al., 1999).

In contrast, the lung transgene expression we observed with endobronchial administration of naked DNA is consistent with most reports on the subject (Tsan et al., 1995; Wheeler et al., 1996; Raczka et al., 1998). Our findings support the ability of naked plasmid DNA to transfect the ciliated epithelium of respiratory bronchioles and the trachea. In contrast, endobronchially administered adenovirus transfects essentially only the alveolar space (Rosenfeld et al., 1991). The lower levels of expression after endobronchial delivery of the DNA-dendrimer complexes as compared with naked plasmid DNA (Table 2) are likely due to preferential clearance of complexes by the mucociliary system before transfection could occur (Clarke and Pavia, 1991). The inhibition of gene transfer by DNA-dendrimer complexes may be mediated by alveolar macrophages, which were reported to represent a barrier to retroviral gene transfer to pulmonary epithelia (McCray et al., 1997) or may result from inefficient endocytosis by the epithelial cells as compared with naked plasmid DNA.

It is difficult to directly compare our data with the expression and tissue distribution reported by others since previously the expression was measured as an enzymatic acetylation activity of CAT. If the amount of acetylated product accurately reflects the amount of enzyme present, then the expression levels of CAT presented in our study should be 20 to 200 times higher than those reported by Meyer et al. (1995). Only the levels of transfection reported in elegant work from the Genzyme group, using the most efficient nonviral system (cationic lipids), 
are twofold higher than our results, although experimental conditions and methods may account for at least part of this difference (Yew et al., 1997). However, the lack of an inflammatory response to our dendrimer vector and the high level of organ specificity observed with DNA-dendrimer complex transfection make our results unique.

In conclusion, expression of DNA transgene in the mouse lung can be achieved either after endobronchial or intravenous administration of plasmid DNA. The utility of complexing DNA with a carrier (dendritic polymer) varies with the route of administration. Moreover, significant levels of transgene expression can be maintained for at least 16 days without inflammation by repeated intravenous doses of dendrimer-DNA complexes. Consequently, intravenously administered G9 dendrimer-DNA complexes are a potentially useful, nonviral vector system for in vivo gene transfer to the alveolar epithelium.

\section{ACKNOWLEDGMENTS}

This work was supported by RO1 AI 40286 from the NIAID. The authors thank Drs. Ron Scheule and Seng Cheng for the pCF1CAT plasmid.

\section{REFERENCES}

Alton, E.W.F.W., Middleton, P.G., CAPlen, N.J., SMITH, S.N., STEEL, D.M., MUNKONGE, F.M., JEFFERY, P.K., GEDDES, D.M., HART, S.L., WILLIAMSON, R., FASOLD, K.I., MILlER, A.D., DICKINSON, P., STEVENSON, B.J., MCLACHLAN, G., DORIN, J.R., and PORTEOUS, D.J. (1993). Non-invasive liposome-mediated gene delivery can correct the ion transport defect in cystic fibrosis mutant mice. Nature Genet. 5, 135-142.

BIELINSKA, A., KUKOWSKA-LATALLO, J.F., JOHNSON, J., TOMALIA, D.A., and BAKER, J.R., JR. (1996). Regulation of in vitro gene expression using antisense oligonucleotides or antisense expression plasmids transfected using starburst PAMAM dendrimers. Nucleic Acids Res. 24, 2176-2182.

BIELINSKA, A.U., KUKOWSKA-LATALLO, J.F., and BAKER, J.R., JR. (1997). The interaction of plasmid DNA with polyamidoamine dendrimers: Mechanism of complex formation and analysis of alterations induced in nuclease sensitivity and transcriptional activity of the complexed DNA. Biochim. Biophys. Acta 1353, 180-190.

BOWDEN, D.H. (1981). Alveolar response to injury. Thorax 2, 357-375.

BRIGHAM, K.L., MEYRICK, B., CHRISTMAN, B., MAGNUSON, M., KING, G., and BERRY, L.C., JR. (1989). In vivo transfection of murine lungs with a functioning procaryotic gene using a liposome vehicle. Am. J. Med. Sci. 298, 278-281.

CANONICO, A.E., CONARY, J.T., MEYRICK, B.O., and BRIGHAM, K.L. (1994). Aerosol and intravenous transfection of human alpha 1-antitrypsin gene to lungs of rabbits. Am. J. Respir. Cell Mol. Biol. 10, 24-29.

CARRINGTON, C.B., GAENSLER, E.A., COUTU, R.E., FITZGERALD, M.X., and GUPTA, R.A. (1978). Natural history and treated course of usual and desquamative interstitial pneumonia. $\underline{\text { N. Engl. J. }}$ Med. 298, 801-809.

CHRISTMAN, B.W., CHRISTMAN, J.W., DWORSKI, R., BLAIR, I.A., and PRAKASH, C. (1993). Prostaglandin $E_{2}$ limits arachidonic acid availability and inhibits leukotriene $B_{4}$ synthesis in rat alveolar macrophages by a nonphospholipase $\mathrm{A}_{2}$ mechanism. $\underline{\mathrm{J} \text {. Immunol. }}$ 151, 2096-2104.
CLARKE, S.W., and PAVIA, D. (1991). Mucociliary clearance. In The Lung: Scientific Foundations. R.G. Crystal and J.B. West, eds. (Raven Press, New York) pp. 1845-1859.

COLLINS. F.S. (1992). Cystic fibrosis: molecular biology and therapeutic implications. Science 256, 774-779.

CONARY, J.T., PARKER, R.E., CHRISTMAN, B.W., FAULKS, R.D., KING, G.A., MEYRICK, B.O., and BRIGHAM, K.L. (1994). Protection of rabbit lungs from endotoxin injury by in vivo hyperexpression of the prostaglandin $\mathrm{G} / \mathrm{H}$ synthase gene. $\underline{\text { J. Clin. Invest. }}$ 93, 1834-1840.

CRYSTAL, R.G., BRANTLY, M.L., HUBBARD, R.C., CURIEL, D.T., STATES, J.T., and HOLMES, M.D. (1989). The alpha ${ }_{1}$-antitrypsin gene and its mutations. Clinical consequences and strategies for therapy. Chest 95, 196-208.

DEMOLY, P., MATHIEU, M., CURIEL, D.T., GODARD, P., BOUSQUET, J., and MICHEL, F.B. (1997). Gene therapy strategies for asthma. Gene Ther. 4, 507-516.

DOW, S.W., SCHWARZE, J., HEATH, T.D., POTTER, T.A., and GELFAND, E.W. (1999). Systemic and local interferon gamma gene delivery to the lungs for treatment of allergen-induced airway hyperresponsiven ess in mice. Hum. Gene Ther. 10, 1905-1914.

HAZINSKI, T.A., LADD, P.A., and DEMATTEO, C.A. (1991). Localization and induced expression of fusion genes in the rat lung. Am. J. Respir. Cell Mol. Biol. 4, 206-209.

HYDE, S.C., GILL, D.R., HIGGINS, C.F., TREZISE, A.E., MacVINISH, L.J., CUTHBERT, A.W., RATCLIFF, R., EVANS, M.J., and COLLEDGE, W.H. (1993). Correction of the ion transport defect in cystic fibrosis transgenic mice by gene therapy. Nature (London) 362, 250-255.

JOHNSON, L.G., OLSEN, J.C., SARKADI, B., MOORE, K.L., SWANSTROM, R., and BOUCHER, R.C. (1992). Efficiency of gene transfer for restoration of normal airway epithelial function in cystic fibrosis. Nature Genet. 2, 21-25.

JOHNSON, L.G., BOYLES, S.E., WILSON, J., and BOUCHER, R.C. (1995). Normalization of raised sodium absorption and raised calcium-mediate d chloride secretion by adenovirus-mediated expression of cystic fibrosis transmembrane conductance regulator in primary human cystic fibrosis airway epithelial cells. J. Clin. Invest. 95, 1377-1382.

KEREM, B.S., ROMMENS, J.M., BUCHANAN, J.A., MARKIEWICZ, D., COX, T.K., CHAKRAVARTI, A., BUCHWALD, M., and TSUI, L.C. (1989). Identification of the cystic fibrosis gene: Genetic analysis. Science 245, 1073-1080.

KUKOWSKA-LATALLO, J.F., BIELINSKA, A.U., JOHNSON, J., SPINDLER, R., TOMALIA, D.A., and BAKER, J.R., JR. (1996). Efficient transfer of genetic material into mammalian cells using Starburst polyamidoamine dendrimers. Proc. Natl. Acad. Sci. U.S.A. 93, 4897-4902.

KUKOWSKA-LATALLO, J.F., CHEN, C., EICHMAN, J., BIELINSKA, A.U., and BAKER, J.R., JR. (1999). Enhancement of dendrimer-mediated transfection using synthetic lung surfactant Exosurf Neonatal in vitro. Biochem. Biophys. Res. Commun. 264, 253-261.

LEE, C.T., CHEN, H.L., and CARBONE, D.P. (1995). Gene therapy for lung cancer. Ann. Oncol. 6(Suppl. 3), 61-63.

LEE, E.R., MARSHALL, J., SIEGEL, C.S., JIANG, C., YEW, N.S., NICHOLS, M.R., NIETUPSKI, J.B., ZIEGLER, R.J., LANE, M., WANG, K.X., WAN, N.C., SCHEULE, R.K., HARRIS, D.J., SMITH, A.E., and CHENG, S.H. (1996). Detailed analysis of structures and formulations of cationic lipids for efficient gene transfer to the lung. Hum. Gene Ther. 7, 1701-1717.

LEE, I., RADOSEVICH, J.A., CHEJFEC, G., MA, Y.X., WARREN, W.H., ROSEN, S.T., and GOULD, V.E. (1986). Malignant mesotheliomas: Improved differential diagnosis from lung carcinomas using monoclonal antibodies 44-3A6 and 624A12. Am. J. Pathol. 123, 497-507.

MACK, C.A., SONG, W.R., CARPENTER, H., WICKHAM, T.J., 
KOVESDI, I., HARVEY, G., MAGOVERN, C.J., ISOM, O.W., ROSENGART, T., FALCK-PEDERSEN, E., HACKETT, N.R., CRYSTAL, R.G., and MASTRANGELI, A. (1997). Circumvention of anti-adenovirus neutralizing immunity by administration of an adenoviral vector of an alternate serotype. Hum. Gene Ther. 8, 99-109.

MASTRANGELI, A., DANEL, C., ROSENFELD, M.A., STRATFORD-PERRICAUDET, L., PERRICAUDET, M., PAVIRANI, A., LECOCQ, J.P., and CRYSTAL, R.G. (1993). Diversity of airway epithelial cell targets for in vivo recombinant adenovirus-mediated gene transfer. J. Clin. Invest. 91, 225-234.

MCCRAY, P.B., JR., WANG, G., KLINE, J.N., ZABNER, J., CHADA, S., JOLLY, D.J., CHANG, S.M.W., and DAVIDSON, B.L. (1997). Alveolar macrophages inhibit retrovirus-mediated gene transfer to airway epithelia. Hum. Gene Ther. 8, 1087-1093.

McELVANEY, M.G., HUBBARD, R.C., BIRRER, P., CHERNICK, M.S., CAPLAN, D.B., FRANK, M.M., and CRYSTAL, R.G. (1991). Aerosol alpha 1-antitrypsin treatment for cystic fibrosis. Lancet 337, 392-394.

MEYER, K.B., THOMPSON, M.M., LEVY, M.Y., BARRON, L.G., and SZOKA, F.C., JR. (1995). Intratracheal gene delivery to the mouse airway: Characterization of plasmid DNA expression and pharmacokinetics. Gene Ther. 2, 450-460.

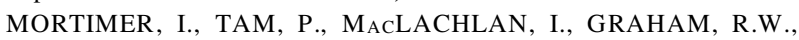
SARAVOLAC, E.G., and JOSHI, P.B. (1999). Cationic lipid-mediated transfection of cells in culture requires mitotic activity. Gene Ther. 6, 403-411.

NALDINI, L., BLOMER, U., GALLAY, P., ORY, D., MULLIGAN, R., GAGE, F.H., VERMA, I.M., and TRONO, D. (1996). In vivo gene delivery and stable transduction of nondividing cells by a lentiviral vector. Science 272, 263-267.

OTTO-VERBERNE, C.J., TEN HAVE-OPBROEK, A.A., FRANKEN, C., HERMANS, J., and DIJKMAN, J.H. (1992). Protective effect of pulmonary surfactant on elastase-induced emphysema in mice. Eur. Respir. J. 5, 1223-1230.

PIGUET, P.F., and VESIN, C. (1994). Treatment by recombinant soluble TNF receptor of pulmonary fibrosis induced by bleomycin or silica in mice. Eur. Respir. J. 7, 515-518.

QIN, L., PAHUD, D.R., DING, Y., BIELINSKA, A.U., KUKOWSKALATALLO, J.F., BAKER, J.R., JR., and BROMBERG, J.S. (1998). Efficient transfer of genes into murine cardiac grafts by starburst polyamidoamin e dendrimers. Hum. Gene Ther. 9, 553-560.

RACZKA, E., KUKOWSKA-LATALLO, J.F., RYMASZEWSKI, M., CHEN, C., and BAKER, J.R., JR. (1998). The effect of synthetic surfactant Exosurf on gene transfer in mouse lung in vivo. Gene Ther. 5, 1333-1339.

RICH, D.P., ANDERSON, M.P., GREGORY, R.J., CHENG, S.H., PAUL, S., JEFFERSON, D.M., MCCANN, J.D., KLINGER, K.W., SMITH, A.E., and WELSH, M.J. (1990). Expression of cystic fibrosis transmembrane conductance regulator corrects defective chloride channel regulation in cystic fibrosis airway epithelial cells. ture (London) 347, 358-363.

RIVERA, V.M., YE, X., COURAGE, N.L., SACHAR, J., CERASOLI, F., JR., WILSON, J.M., and GILMAN, M. (1999). Long-term regulated expression of growth hormone in mice after intramuscular gene transfer. Proc. Natl. Acad. Sci. U.S.A. 96, 8657-8662.

ROBBINS, P.D., and GHIVIZZANI, S.C. (1998). Viral vectors for gene therapy. Pharmacol. Ther. 80, 35-47.

ROGY, M.A., AUFFENBERG, R., ESPAT, N.J., PHILIP, R., REMICK, D., WOLLENBERG, G.K., COPELAND, E.M., III, and MOLDAWER, L.L. (1995). Human tumor necrosis factor receptor (p55) and interleukin 10 gene transfer in the mouse reduces mortality to lethal endotoxemia and also attenuates local inflammatory responses. J. Exp. Med. 181, 2289-2293.

ROSENFELD, M.A., SIEGFRIED, W., YOSHIMURA, K., YONEYAMA, K., FUKAYAMA, M., STIER, L.E., PAAKKO, P.K.,
GILARDI, P., STRATFORD-PERRICAUDET, L.D., PERRICAUDET, M., JALlAT, S., PAVIRANI, A., LECOCQ, J.P., and CRYSTAL, R.G. (1991). Adenovirus-mediated transfer of a recombinant alpha 1-antitrypsin gene to the lung epithelium in vivo. Science 252, 431-434.

ROSENFELD, M.A., YOSHIMURA, K., TRAPNELL, B.C., YONEYAMA, K., ROSENTHAL, E.R., DALEMANS, W., FUKAYAMA, M., BARGON, J., STIER, L.E., STRATFORD-PERRICAUDET, L., PERRICAUDET, M., GUGGINO, W.B., PAVIRANI, A., LECOCQ, J.P., and CRYSTAL, R.G. (1992). In vivo transfer of the human cystic fibrosis transmembrane conductance regulator gene to the airway epithelium. Cell 68, 143-155.

SCHUGHART, K., BISCHOFF, R., ALI HADJI, D., BOUSIFF, O., PERRAUD, F., ACCART, N., RASMUSSEN, U.B., PAVIRANI, A., VAN ROOIJEN, N., and KOLBE, H.V.J. (1999). Effect of liposomeencapsulated clodronate pretreatment on synthetic vector-mediated gene expression in mice. Gene Ther. 6, 448-453.

STRIBLING, R., BRUNETTE, E., LIGGITT, D., GAENSLER, K., and DEBS, R. (1992). Aerosol gene delivery in vivo. Proc. Natl. Acad. Sci. U.S.A. 89, 11277-11281.

TAYA, Y., HOSOGAI, K., HIROHASHI, S., SHIMOSATO, Y., TSUCHIYA, R., TSUCHIDA, N., FUSHIMI, M., SEKIYA, T., and NISHIMURA, S. (1984). A novel combination of Ki-ras and $m y c$ amplification accompanied by point mutational activation of Ki-ras in a human lung cancer. EMBO J. 3, 2943-2946.

TRAPNELL, B.C., CHU, C.S., PAAKKO, P.K., BANKS, T.C., YOSHIMURA, K., FERRANS, V.J., CHERNICK, M.S., and CRYSTAL, R.G. (1991). Expression of the cystic fibrosis transmembrane conductance regulator gene in the respiratory tract of normal individuals and individuals with cystic fibrosis. Proc. Natl. Acad. Sci. U.S.A. 88, 6565-6569.

TSAN, M.F., WHITE, J.E., and SHEPHARD, B. (1995). Lung-specific direct in vivo gene transfer with recombinant plasmid DNA. Am. J. Physiol. 268, L1052-L1056.

TURNER-WARWICK, M., BURROWS, S.B., and JOHNSON, A. (1980). Cryptogenic fibrosing alveolitis: Clinical features and their effects on survival. Thorax 35, 171-180.

WAGNER, J.A., CHAO, A.C., and GARDNER, P. (1995). Molecular strategies for therapy of cystic fibrosis. Annu. Rev. Pharmacol. Toxicol. 35, 257-276.

WANG, P., WU, P., SIEGEL, M.I., EGAN, R.W., and BILLAH, M.M. (1994). IL-10 inhibits transcription of cytokine genes in human peripheral mononuclear cells. J. Immunol. 153, 811-816.

WHEELER, C.J., FELGNER, P.L., TSAI, Y.J., MARSHALL, J., SUKHU, L., DOH, S.G., HARTIKKA, J., NIETUPSKI, J., MANTHORPE, M., NICHOLS, M., PLEWE, M., LIANG, X., NORMAN, J., SMITH, A., and CHENG, S.H. (1996). A novel cationic lipid greatly enhances plasmid DNA delivery and expression in mouse lung. Proc. Natl. Acad. Sci. U.S.A. 93, 11454-11459.

WORGALL, S., WOLFF, G., FALCK-PEDERSEN, E., and CRYSTAL, R.G. (1997). Innate immune mechanisms dominate elimination of adenoviral vectors following in vivo administration. $\underline{\text { Hum. }}$ Gene Ther. 8, 37-44.

XIAO, W., CHIRMUle, N., BERTA, S.C., McCUllough, B., GAO, G., and WILSON, J.M. (1999). Gene therapy vectors based on adeno-associated virus type 1. J. Virol. 73, 3994-4003.

YANG, Y., NUNES, F.A., BERENCSI, K., FURTH, E.E., GONCZOL, E., and WILSON, J.M. (1994). Cellular immunity to viral antigens limits E1-deleted adenovirus for gene therapy. Proc. Natl. Acad. Sci. U.S.A. 91, 4407-4411.

YEI, S., MITTEREDER, N., TANG, K., O'SUlliVAN, C., and TRAPNELL, B.C. (1994). Adenovirus-mediated gene transfer for cystic fibrosis: Quantitative evaluation of repeated in vivo vector administration in the lung. Gene Ther. 1, 192-200.

YEW, N.S., WYSOKENSKI, D.M., WANG, K.X., ZIEGLER, R.J., 
MARShAll, J., McNEILly, D., CHERRY, M., OSBURN, W., and CHENG, S.H. (1997). Optimization of plasmid vectors for highlevel expression in lung epithelial cells. Hum. Gene Ther. 8, 575-584.

ZABNER, J., COUTURE, L.A., GREGORY, R.J., GRAHAM, S.M., SMITH, A.E., and WELSH, M.J. (1993). Adenovirus-mediated gene transfer transiently corrects the chloride transport defect in nasal epithelia of patients with cystic fibrosis. Cell 5, 207-216.

ZABNER, J., PETERSEN, D.M., PUGA, A.P., GRAHAM, S.M., COUTURE, L.A., KEYES, L.D., LUKASON, M.J., ST. GEORGE, J.A., GREGORY, R.J., SMITH, A.E., and WELSH, M.J. (1994). Safety and efficacy of repetitive adenovirus-mediated transfer of CFTR cDNA to airway epithelia of primates and cotton rats. Nature Genet. 6, 75-83.

ZABNER, J., CHENG, S.H., MEEKER, D., LAUNSPACH, J., BALFOUR, R., PERRICONE, M.A., MORRIS, J.E., MARSHALL, J., FASBENDER, A., SMITH, A.E., and WELSH, M.J. (1997). Comparison of DNA-lipid complexes and DNA alone for gene transfer to cystic fibrosis airway epithelia in vivo. J. Clin. Invest, 100, $1529-1537$.

ZHU, N., LIGGITT, D., LIU, Y., and DEBS, R. (1993). Systemic gene expression after intravenous DNA delivery into adult mice. S Science 261, 209-211.

Address reprint requests to: Dr. James R. Baker, Jr. Department of Internal Medicine 9220 MSRB III University of Michigan Medical School Ann Arbor, MI 48109-0648

Received for publication February 1, 2000; accepted after revision April 17, 2000. 
This article has been cited by:

1. Venkataswarup Tiriveedhi, Peter Butko. 2008. Soluble Glycosaminoglycans Inhibit the Interaction of TAT-PTD with Lipid Vesicles. International Journal of Peptide Research and Therapeutics 14:3, 209-214. [CrossRef]

2. Yiyun Cheng, Zhenhua Xu, Minglu Ma, Tongwen Xu. 2008. Dendrimers as drug carriers: Applications in different routes of drug administration. Journal of Pharmaceutical Sciences 97:1, 123-143. [CrossRef]

3. Marine Guillot-Nieckowski, Sara Eisler, François Diederich. 2007. Dendritic vectors for gene transfection. New Journal of Chemistry 31:7, 1111. [CrossRef]

4. Dwaine F Emerich, Christopher G Thanos. 2003. Nanotechnology and medicine. Expert Opinion on Biological Therapy 3:4, 655-663. [CrossRef]

5. Xianmin Meng, Daisuke Sawamura, Shinsuke Ina, Katsuto Tamai, Katsumi Hanada, Isao Hashimoto. 2002. Keratinocyte gene therapy: cytokine gene expression in local keratinocytes and in circulation by introducing cytokine genes into skin. Experimental Dermatology 11:5, 456-461. [CrossRef]

6. Benjamin Kozower, Samer Kanaan, Stephen Cassivi, G. Patterson. 2001. Current Opinion in Organ Transplantation 6:3, 248-252. [CrossRef] 